\title{
Giải pháp hoàn thiện quản lý dự án đầu tư xây dụng tại quỹ đầu tư phát triển tỉnh Thái Nguyên
}

\section{Solutions for improving the management of onstruction investment project at Thai Nguyen investment and development fund}

\author{
Vũ Thị Hậu ${ }^{*}$, Mai Xuân Trọng ${ }^{2}$ \\ ${ }^{1}$ Trường Đại học Kinh tế \& Quản trị kinh doanh, Việt Nam \\ ${ }^{2}$ Quỹ Đầu tư phát triển tỉnh Thái Nguyên, Việt Nam \\ *Tác giả liên hệ, Email: vuthihau@tueba.edu.vn
}

\section{THÔNG TIN}

DOI: $10.46223 / \mathrm{HCMCOUJS}$. econ.vi.15.3.1333.2020

Ngày nhận: 03/01/2020

Ngày nhận lại: 07/02/2020

Duyệt đăng: 10/02/2020

\section{Tù khóa:}

quản lý, dự án đầu tư xây dựng, quỹ đầu tư phát triển địa phương

Keywords:

management, construction investment projects, local investment and development fund

\section{TÓM TẮT}

Dựa trên cơ sở chức năng, nhiệm vụ của Quỹ Đầu tư phát triển tỉnh Thái Nguyên, bài viết đã đánh giá hiện trạng quản lý dự án đầu tư xây dựng giai đoạn 2016 - 2018, thông qua nghiên cứu điển hình trường hợp 07 dự án đã và đang triển khai thực hiện do Quỹ Đầu tư phát triển tỉnh Thái Nguyên là chủ đầu tư. Kết quả nghiên cứu cho thấy công tác quản lý dự án đầu tư xây dựng của Quỹ Đầu tư phát triển tỉnh Thái Nguyên đã có những thành tựu và hạn chế nhất định trên cả ba phương diện: quy trình quản lý, nội dung quản lý và công cụ quản lý. Trên cơ sở đó, bài viết đã chỉ rõ hạn chế và nguyên nhân của những hạn chế, tạo tiền đề khoa học đề xuất một số giải pháp hoàn thiện quản lý dự án đầu tư xây dựng tại Quỹ Đầu tư phát triển tỉnh Thái Nguyên trong thời gian tới.

\section{ABSTRACT}

According to the functions and responsibility of Thai Nguyen Investment and Development Fund, this study analyzed the management of construction investment projects from 2016 to 2018 by examining 07 projects implemented by Thai Nguyen Investment and Development Fund. The analysis results show that there are achievements and limitations found in all three aspects of management procedure, management content, and management tools. Based on the research findings, this paper discusses the drawbacks and the causes of these drawbacks in order to propose some recommendations to improve the management of construction investment projects at Thai Nguyen Investment and Development Fund in the future.

\section{1. Đặt vấn đề}

Quỹ Đầu tư phát triển tỉnh Thái Nguyên là tổ chức tài chính Nhà nước, được thành lập theo Quyết định số 26/QĐ-UBND ngày 07/01/2016 của UBND tỉnh Thái Nguyên. Quỹ Đầu tư phát triển tỉnh Thái Nguyên có chức năng và nhiệm vụ chính là tiếp nhận vốn ngân sách, vốn viện trợ, tài trợ hoặc ủy thác, huy động vốn từ cá nhân, tổ chức trong và ngoài nước để thực hiện nhiệm vụ dự án phát triển cơ sở hạ tầng kinh tế - xã hội của tỉnh Thái Nguyên. Dựa trên cơ sở chức năng và 
nhiệm vụ của Quỹ Đầu tư phát triển tỉnh Thái Nguyên, bài viết tập trung đánh giá hiện trạng quản lý dự án đầu tư xây dựng giai đoạn 2016 - 2018, thông qua nghiên cứu điển hình đối với 07 dự án đã và đang triển khai thực hiện do Quỹ Đầu tư phát triển tỉnh Thái Nguyên là chủ đầu tư. Trên cơ sở đó, bài viết chỉ rõ hạn chế và nguyên nhân của những hạn chế, tạo tiền đề khoa học đề xuất một số giải pháp hoàn thiện quản lý dự án đầu tư xây dựng tại Quỹ Đầu tư phát triển tỉnh Thái Nguyên trong thời gian tới.

\section{Các định nghĩa về "quỹ đầu tư phát triển địa phương" và "quản lý dự án đầu tư xây dựng của quỹ đầu tư phát triển địa phương"}

Quỹ đầu tư phát triển địa phương là một tổ chức tài chính Nhà nước của địa phương; thực hiện chức năng đầu tư tài chính và đầu tư phát triển. Quỹ đầu tư phát triển địa phương (Quỹ) có tư cách pháp nhân, có vốn điều lệ, có bảng cân đối kế toán riêng, có con dấu, được mở tài khoản tại Kho bạc Nhà nước và các ngân hàng thương mại hoạt động hợp pháp tại Việt Nam. Quỹ thực hiện các hoạt động trong đầu tư, bao gồm đầu tư trực tiếp vào các dự án; cho vay đầu tư; góp vốn thành lập doanh nghiệp hoạt động trong các lĩnh vực phát triển kết cấu hạ tầng kinh tế - xã hội... Đối tượng cho vay là các dự án đầu tư kết cấu hạ tầng có phương án thu hồi vốn trực tiếp thuộc các chương trình, mục tiêu theo chiến lược, kế hoạch phát triển kinh tế - xã hội đã được Hội đồng nhân dân cấp tỉnh thông qua, bao gồm: các dự án về giao thông; cấp nước; nhà ở khu đô thị, khu dân cư; di chuyển sắp xếp lại các cơ sở sản xuất; xử lý rác thải của các đô thị; các dự án quan trọng do Ủy ban nhân dân cấp tỉnh quyết định.

Quản lý dự án đầu tư xây dựng của Quỹ Đầu tư phát triển địa phương là việc Quỹ lập kế hoạch, sử dụng nguồn vốn, thời gian và giám sát thực hiện dự án nhằm mục tiêu hoàn thành dự án đúng kế hoạch, yêu cầu và chất lượng đã đề ra bằng các phương pháp cụ thể. Quy trình quản lý dự án đầu tư xây dựng của Quỹ bao gồm các bước: nghiên cứu cơ hội đầu tư; khảo sát dự án đầu tư; lập báo cáo nghiên cứu khả thi; nguồn vốn đầu tư của dự án; tìm nguồn nhân lực cho dự án; tổ chức thẩm định dự án; trình phê duyệt dự án đầu tư; thực hiện dự án đầu tư; nghiệm thu, thanh toán, quyết toán. Quỹ thực hiện nhiệm vụ quản lý dự án đầu tư xây dựng thông qua các nội dung quản lý: quá trình thẩm định, chi phí thực hiện dự án, lựa chọn nhà thầu, chất lượng xây dựng, tiến độ thi công. Quản lý dự án đầu tư xây dựng tại Quỹ thông qua các công cụ: pháp luật, kế hoạch, mục lục ngân sách nhà nước và hạch toán kế toán...

\section{Phương pháp nghiên cứu}

\section{- Phuoong pháp thu thập thông tin:}

+ Thu thập thông tin thứ cấp về quản lý dự án đầu tư xây dựng tại Quỹ Đầu tư phát triển tỉnh Thái Nguyên thông qua các báo cáo tổng kết hàng năm về công tác quản lý dự án đầu tư trên địa bàn tỉnh Thái Nguyên của các đơn vị có chức năng thực hiện dự án trong giai đoạn 2016 2018. Ngoài ra, thông tin thứ cấp được thu thập trên cơ sở các nghiên cứu đã có về quản lý dự án đầu tư xây dựng, các văn bản Luật/Nghị định/Thông tư hướng dẫn về quản lý dự án đầu tư xây dựng và các văn bản pháp lý hiện hành khác...

+ Thông tin sơ cấp được thu thập từ kết quả điều tra khảo sát đánh giá hiện trạng nội dung quản lý dự án đầu tư xây dựng tại Quỹ Đầu tư phát triển tỉnh Thái Nguyên tháng 05/2019 đối với 07 dự án do Quỹ làm chủ đầu tư từ năm 2016 - 2018 bao gồm: Khu dân cư và khu tái định cư xóm Trung, xã Điềm Thụy, huyện Phú Bình; Khu dân cư tổ dân phố số 4, thị trấn Hương sơn, huyện Phú Bình; Khu dân cư số 6 Thịnh Đán (giai đoạn 2); Khu dân cư số 4, phường Tân Thịnh, thành phố Thái Nguyên; Khu dân cư số 3, phường Trưng Vương, thành phố Thái Nguyên; Khu dân cư số 4, phường Trưng Vương, thành phố Thái Nguyên; Khu dân cư số 10 phường Phan Đình Phùng, thành phố Thái Nguyên. Quy mô mẫu chọn là 190 người là cán bộ, lãnh đạo, nhà thầu xây lắp, tư vấn đã và đang thực hiện 07 dự án do Quỹ Đầu tư phát triển tỉnh Thái Nguyên làm Chủ đầu tư. 
Bảng 1 minh họa thang đo Likert 5 mức độ: 1- Rất không đồng ý (RKĐY); 2- Không đồng ý (KĐY); 3- Bình thường (BT); 4- Đồng ý (ĐY) và; 5- Rất đồng ý (RĐY) để đánh giá nội dung quản lý dự án đầu tư xây dựng tại Quỹ Đầu tư phát triển tỉnh Thái Nguyên.

\section{Bảng 1}

Thang đo đánh giá nội dung quản lý dự án đầu tư xây dựng

\begin{tabular}{|c|c|c|c|c|c|}
\hline \multirow{2}{*}{ Nội dung quản lý dự án đầu tư xây dựng } & 1 & 2 & 3 & 4 & 5 \\
\hline & RKĐY & KĐY & BT & $Đ Y$ & RĐY \\
\hline \multicolumn{6}{|l|}{ 1. Quản lý quá trình lập dụ án } \\
\hline \multicolumn{6}{|l|}{ 1.1. Tiến độ lập dự án } \\
\hline \multicolumn{6}{|l|}{ 1.2. Khái toán chi phí trong lập dự toán } \\
\hline \multicolumn{6}{|l|}{ 1.3. Tư vấn lập dự án } \\
\hline \multicolumn{6}{|l|}{ 1.4. Giám sát tư vấn lập dự án } \\
\hline \multicolumn{6}{|l|}{ 1.5. Xin phê duyệt dự án } \\
\hline \multicolumn{6}{|l|}{ 2. Quản lý quá trình thẩm định } \\
\hline \multicolumn{6}{|l|}{ 2.1. Hồ sơ thẩm định xây dựng } \\
\hline \multicolumn{6}{|c|}{ 2.2. Thời gian thẩm định } \\
\hline \multicolumn{6}{|c|}{ 2.3. Năng lực và kinh nghiệm của cán bộ thẩm định } \\
\hline \multicolumn{6}{|l|}{ 2.4. Trình tự thẩm định } \\
\hline \multicolumn{6}{|l|}{ 3. Quản lý lưa chọn nhà thầu } \\
\hline \multicolumn{6}{|l|}{ 4.1. Năng lực pháp lý của nhà thầu } \\
\hline \multicolumn{6}{|l|}{ 4.2. Quản lý phương pháp lựa chọn nhà thầu } \\
\hline \multicolumn{6}{|l|}{ 4.3. Thời gian lựa chọn nhà thầu } \\
\hline \multicolumn{6}{|l|}{ 4. Quản lý chất lương xây dụng } \\
\hline \multicolumn{6}{|l|}{ 5.1. Quản lý chất lượng công trình tại thực địa } \\
\hline \multicolumn{6}{|l|}{ 5.2. Chất lượng đầu tư xây dựng ngoài thực địa } \\
\hline \multicolumn{6}{|l|}{ 5.3. Giám sát thực hiện thi công } \\
\hline \multicolumn{6}{|l|}{ 5. Quản lý tiến độ thi công dụ án } \\
\hline \multicolumn{6}{|l|}{ 6.1. Cán bộ thực hiện giám sát tiến độ dự án } \\
\hline \multicolumn{6}{|l|}{ 6.2. Nhà thầu thi công thực hiện tiến độ dự án } \\
\hline 6.3. Tiến độ dự án theo kế hoạch phê duyệt & & & & & \\
\hline
\end{tabular}

Nguồn: Tác giả xây dựng

- Phương pháp tổng hợp và xủ lý thông tin: Đối với thông tin sơ cấp, được tổng hợp thông qua phần mềm Microsoft Excel, phân loại trên cơ sở nội dung quản lý dự án đầu tư xây dựng như: quản lý quá trình lập dự án, quản lý quá trình thẩm định, quản lý chi phí thực hiện dự án, quản lý lựa chọn nhà thầu, quản lý chất lượng xây dựng, quản lý tiến độ thi công. Đối với thông tin thứ cấp qua các nguồn văn bản/công văn của các đơn vị trên địa bàn tỉnh Thái Nguyên, sàng lọc những thông tin quan trọng bởi đây là các thông tin phản ánh việc thực hiện quản lý các dự án đầu tư xây dựng trên địa bàn tỉnh Thái Nguyên, có độ tin cậy cao.

- Phuoong pháp phân tích thông tin: Trên cơ sở dữ liệu đã được thu thập và tổng hợp, tác 
giả sử dụng phương pháp tính toán, so sánh, phân tích và đánh giá để mô tả hiện trạng và trình bày giải pháp hoàn thiện quản lý dự án đầu tư xây dựng tại Quỹ Đầu tư phát triển tỉnh Thái Nguyên trong thời gian tới.

\section{Kết quả nghiên cứu}

\subsection{Thục trạng quản lý dụ án đầu tư tại Quỹ đầu tư phát triển tỉnh Thái Nguyên}

\subsubsection{Quy trình quản lý dụ án đầu tu tại Quỹ Đầu tu phát triển tỉnh Thái Nguyên}

Quy trình quản lý dự án đầu tư xây dựng tại Quỹ Đầu tư phát triển tỉnh Thái Nguyên bao gồm hai giai đoạn chính: chuẩn bị đầu tư và thực hiện đầu tư. Giai đoạn chuẩn bị đầu tư bao gồm các quy trình: xin chủ trương; xin quy hoạch; lập dự án; bồi thường, thu hồi đất. Giai đoạn thực hiện đầu tư bao gồm quy trình: thực hiện thi công và nghiệm thu thanh toán. Sơ đồ 1 và 2 là minh họa quy trình lập dự án và quy trình thực hiện thi công dự án đầu tư xây dựng tại Quỹ Đầu tư phát triển tỉnh Thái Nguyên.

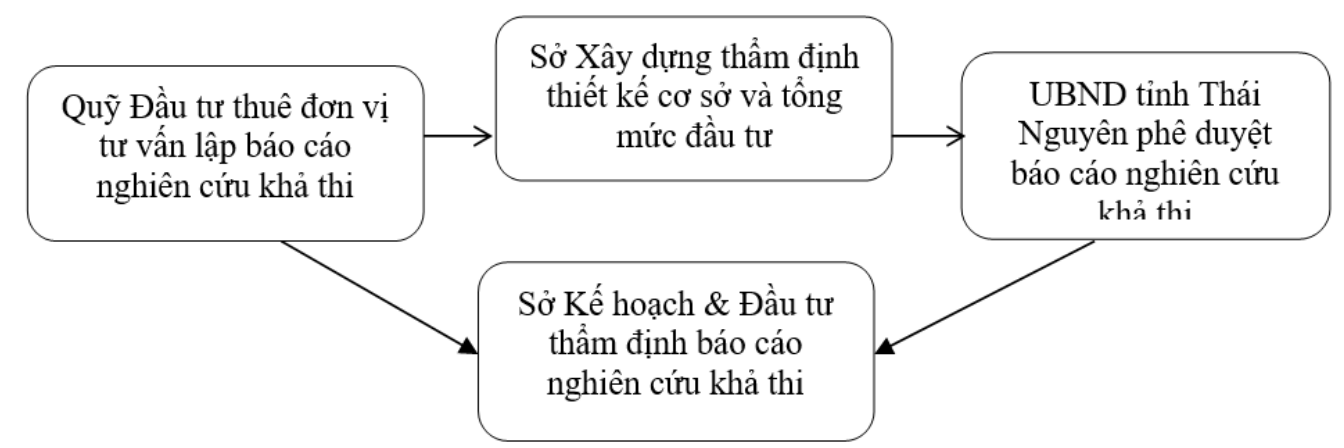

Hình 1. Quy trình lập dự án đầu tư xây dựng

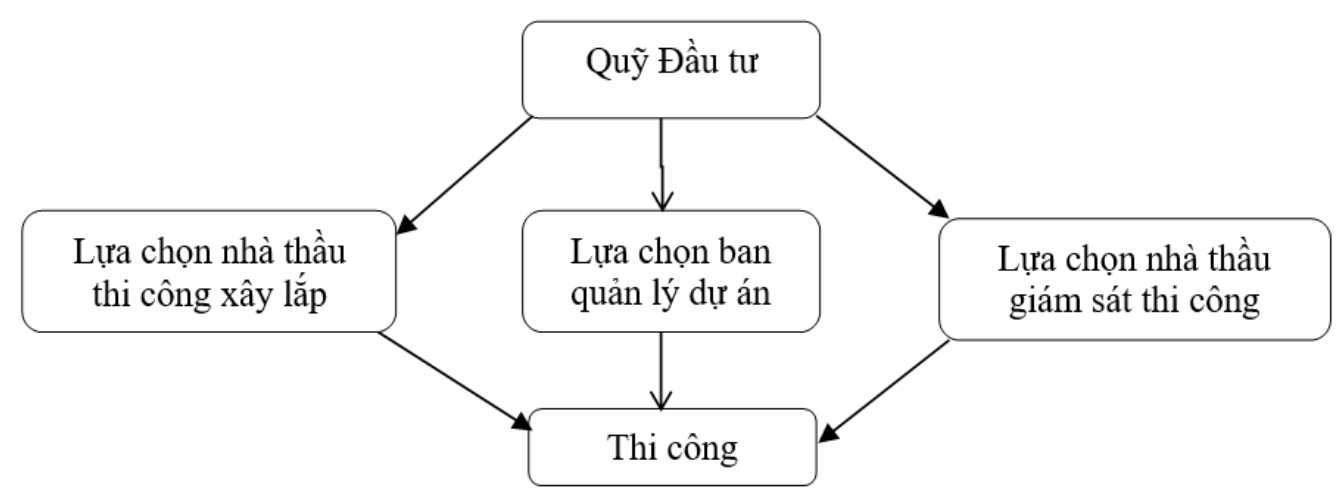

Hình 2. Quy trình thực hiện thi công dự án đầu tư xây dựng

Nguồn: Quỹ Đầu tư phát triển tỉnh Thái Nguyên và tổng hợp của tác giả

\subsubsection{Nội dung quản lý dụ án đầu tu tại Quỹ Đầu tu phát triển tỉnh Thái Nguyên}

Quản lý quá trình lập dụ án

Kết quả điều tra từ các bên liên quan đến quản lý quá trình lập dự án tại Quỹ cho thấy $85.7 \%$ ý kiến đồng ý với việc quản lý quá trình lập dự án, $12.0 \%$ ý kiến cho rằng quản lý quá trình lập dự án ở mức bình thường, 2.3\% ý kiến không đồng ý với cách quản lý quá trình lập dự án. Các dự án như Khu dân cư số 10 phường Phan Đình Phùng, Khu dân cư số 4 phường Tân Thịnh, Khu dân cư số 3,4 phường Trưng Vương đều được các đơn vị tán thành với chỉ tiêu sự phù hợp với chiến lược phát triển kinh tế vùng. Bên cạnh đó là nhu cầu của người dân xung quanh khu vực thực hiện dự án cũng như người dân trong hoặc ngoài thành phố đối với sản phẩm dự án là khá 
cao, do vậy sản phẩm của dự án là đất ở tính thời điểm hoàn thiện dự án hoặc thời điểm sau dự án luôn có tiềm năng phát triển. Trên phương diện tài chính, các dự án nói trên đều mang lại nguồn thu cho NSNN thông qua việc nộp tiền thuế sử dụng đất.

Nội dung quản lý được đánh giá là hạn chế trong quá trình lập dự án là tiến độ lập dự án và năng lực của đơn vị tư vấn lập dự án. Lập dự án không đúng tiến độ là do đơn vị tư vấn triển khai thực hiện lập dự án ngoài thực địa và tính toán các hạng mục còn chưa sát sao. Yếu tố ngoại cảnh cũng tác động đến quá trình lập dự án như thời tiết hoặc người dân trong vùng lập dự án chưa thực sự hiểu về lợi ích của dự án mang lại cho kinh tế vùng nơi thực hiện dự án. Năng lực của đơn vị tư vấn lập dự án bao gồm máy móc thực hiện ngoài thực địa và quá trình nội nghiệp, con người thực hiện các công việc. Trên thực tế, hầu hết các dự án đều đáp ứng được yếu tố nhân lực và máy móc thiết kế. Tuy nhiên có 2 dự án là Khu dân cư số 3 và Khu dân cư số 4 , phường Trưng Vương chưa đáp ứng được yêu cầu kỹ thuật của Chủ đầu tư. Chẳng hạn, số lượng nhân công và máy móc không đủ dẫn tới tình trạng chậm tiến độ thực hiện và thời gian hoàn thành khối lượng so với dự kiến trong hợp đồng đã ký kết.

\section{Quản lý quá trình thẩm định}

Kết quả điều tra cho thấy quản lý quá trình thẩm định dự án cơ bản thống nhất với $91.4 \%$ ý kiến đồng ý. Điều đó cho thấy các dự án thực hiện của Quỹ Đầu tư hầu hết đều đáp ứng được chỉ tiêu về quản lý thẩm định dự án. Về tính pháp lý, các dự án của Quỹ khi gửi thẩm định đều có đầy đủ các giấy tờ pháp lý làm căn cứ thực hiện dự án. Chẳng hạn, khi gửi thẩm định phần báo cáo nghiên cứu khả thi (lập dự án), đơn vị tư vấn sẽ tư vấn cho Chủ đầu tư bộ hồ sơ bao gồm thuyết minh dự án, báo cáo kinh tế kỹ thuật dự án và các bản vẽ thuộc trong dự án kèm theo là các quyết định như quyết định phê duyệt quy hoạch chi tiết $1 / 500$, quyết định phê duyệt nhiệm vụ, quyết

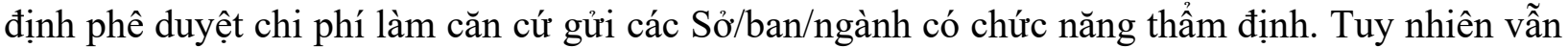
tồn tại $8.6 \%$ ý kiến không đồng ý trong quản lý quá trình thẩm định. Điều này là do một số dự án, việc trình thẩm định vẫn còn nhiều thiếu sót như hồ sơ thẩm định chưa đầy đủ, sau khi cán bộ thẩm định có yêu cầu bổ sung thì đơn vị tư vấn thực hiện bổ sung hồ sơ còn chậm dẫn tới thời gian thẩm định bị kéo dài gây lãng phí thời gian dự án và tiến độ thực hiện chậm so với dự kiến.

Kết quả nghiên cứu ở bảng 2 cho thấy chi phí đầu tư dự án và tổng doanh thu $\left(\mathrm{G}_{\mathrm{kt}}\right)$ của 07 dự án có sự khác biệt. Trong đó, Chi phí đầu tư dự kiến bao gồm Suất vốn đầu tư của dự án $\left(\mathrm{S}_{\mathrm{v} \text { đt }}\right)$, Lãi vay thực hiện dự án $\left(\mathrm{L}_{S}\right)$, Chi phí dự phòng của dự án $\left(\mathrm{C}_{\mathrm{dp}}\right)$ và Chi phí bồi thường giải phóng mặt bằng $\left(\mathrm{C}_{\mathrm{bt}}\right)$. Hiệu quả kinh tế dự án được xác định theo công thức: $\mathrm{G}_{\mathrm{td}}=\mathrm{G}_{\mathrm{kt}}-\left(\mathrm{S}_{\mathrm{v} \text { tt }}+\mathrm{L}_{\mathrm{s}}+\mathrm{C}_{\mathrm{dp}}\right.$ $+\mathrm{C}_{\mathrm{bt}}$ ). Do vị trí dự án nằm tại địa bàn phường trung tâm thành phố hoặc thuộc địa bàn xã ở huyện mà có sự sai khác về hiệu quả kinh tế. Chẳng hạn, dự án Khu dân cư số 10 phường Phan Đình Phùng với mức đầu tư dự kiến là 49 tỷ đồng, tổng doanh thu dự án là 64 tỷ đồng và hiệu quả kinh tế là 15 tỷ đồng. Bên cạnh đó là dự án Khu dân cư và khu tái định cư xóm Trung, xã Điềm Thụy, huyện Phú Bình với mức đầu tư dự kiến là 85 tỷ đồng lớn hơn gần gấp đôi so với khu dân cư số 10 , phường Phan Đình Phùng, tuy nhiên hiệu quả kinh tế dự kiến vẫn thấp hơn so với dự án thuộc các phường ở khu vực thành phố. 


\section{Bảng 2}

Dự kiến hiệu quả kinh tế $\left(\mathrm{G}_{\mathrm{dt}}\right)$ của các dự án đầu tư xây dựng

Đơn vị: Tỷ đồng

\begin{tabular}{|c|c|c|c|c|}
\hline STT & Tên dụ̣ án & $\begin{array}{c}\text { Chi phí đầu tư } \\
\left(S_{\text {vdt }}+L_{S}+C_{d p}+C_{b t}\right)\end{array}$ & $\begin{array}{l}\text { Tổng doanh } \\
\text { thu }\left(\mathbf{G}_{\mathrm{kt}}\right)\end{array}$ & $\begin{array}{l}\text { Hiệu quả } \\
\text { kinh tế }\left(\mathbf{G}_{\mathbf{d t}}\right)\end{array}$ \\
\hline 01 & $\begin{array}{l}\text { Khu dân cư và khu tái định cư xóm Trung, xã } \\
\text { Điềm Thụy, huyện Phú Bình }\end{array}$ & 85 & 98 & 13 \\
\hline 02 & $\begin{array}{l}\text { Khu dân cư tổ dân phố số } 4 \text { thị trấn Hương } \\
\text { Sơn, huyện Phú Bình }\end{array}$ & 74 & 90 & 16 \\
\hline 03 & Khu dân cư số 6 Thịnh Đán (giai đoạn 2) & 42 & 56 & 14 \\
\hline 04 & $\begin{array}{l}\text { Khu dân cư số } 4 \text {, phường Tân Thịnh, thành } \\
\text { phố Thái Nguyên }\end{array}$ & 68.5 & 82 & 13.5 \\
\hline 05 & $\begin{array}{l}\text { Khu dân cư số } 3 \text {, phường Trưng Vương, } \\
\text { thành phố Thái Nguyên }\end{array}$ & 6.7 & 11 & 4.3 \\
\hline 06 & $\begin{array}{l}\text { Khu dân cư số } 4 \text {, phường Trưng Vương, } \\
\text { thành phố Thái Nguyên }\end{array}$ & 5.1 & 6.8 & 1.7 \\
\hline 07 & $\begin{array}{l}\text { Khu dân cư số } 10 \text {, phường Phan Đình } \\
\text { Phùng, thành phố Thái Nguyên }\end{array}$ & 49 & 64 & 15 \\
\hline
\end{tabular}

Nguồn: Quỹ Đầu tư phát triển tỉnh Thái Nguyên và tính toán của tác giả

\section{Quản lý chi phí thực hiện dự án}

Xét trên góc độ chung thì dự án bao gồm các phần chi phí thực hiện của các giai đoạn như chi phí lập dự án, chi phí đền bù giải phóng mặt bằng, chi phí các gói thầu xây lắp, chi phí quản lý dự án, chi phí dự phòng và các chi phí khác. Quản lý chi phí thực hiện dự án của Quỹ là việc giám sát từng gói thầu thực hiện trong dự án được tính theo tiến độ của các hạng mục so với hợp đồng đã đề ra giữa Chủ đầu tư và đơn vị tư vấn hoặc thi công đã ký kết sao cho phù hợp. Căn cứ vào khối lượng hoàn thiện tính theo hợp đồng đã ký kết, Chủ đầu tư là Quỹ sẽ tiến hành giải ngân theo khối lượng hoàn thành công việc. Quản lý chi phí của các gói thầu thi công xây lắp phải đảm bảo đúng quy định của nhà nước, đúng hợp đồng đã ký kết. Bên cạnh đó thì nhà thầu thực hiện thi công phải đảm bảo được khối lượng thi công theo đúng với dự toán đã đề ra, đúng theo thiết kế đã ký kết với Chủ đầu tư để đảm bảo tính đúng các chi phí làm cơ sở thực hiện dự án một cách thuận lợi. Bảng 3 dưới đây minh họa một phần các gói thầu tư vấn lập dự án và thi công dự án.

\section{Quản lý chi phí thực hiện dư án}

Xét trên góc độ chung thì dự án bao gồm các phần chi phí thực hiện của các giai đoạn như chi phí lập dự án, chi phí đền bù giải phóng mặt bằng, chi phí các gói thầu xây lắp, chi phí quản lý dự án, chi phí dự phòng và các chi phí khác. Quản lý chi phí thực hiện dự án của Quỹ là việc giám sát từng gói thầu thực hiện trong dự án được tính theo tiến độ của các hạng mục so với hợp đồng đã đề ra giữa Chủ đầu tư và đơn vị tư vấn hoặc thi công đã ký kết sao cho phù hợp. Căn cứ vào khối lượng hoàn thiện tính theo hợp đồng đã ký kết, Chủ đầu tư là Quỹ sẽ tiến hành giải ngân theo khối lượng hoàn thành công việc. Quản lý chi phí của các gói thầu thi công xây lắp phải đảm bảo đúng quy định của nhà nước, đúng hợp đồng đã ký kết. Bên cạnh đó thì nhà thầu thực hiện thi công phải đảm bảo được khối lượng thi công theo đúng với dự toán đã đề ra, đúng theo thiết kế đã ký kết với Chủ đầu tư để đảm bảo tính đúng các chi phí làm cơ sở thực hiện dự án một cách thuận lợi. Bảng 3 dưới đây minh họa một phần các gói thầu tư vấn lập dự án và thi công dự án. 


\section{Bảng 3}

Một số gói thầu có chi phí thực hiện trong dự án

\begin{tabular}{|c|l|l|}
\hline STT & \multicolumn{1}{|c|}{ Tên đơn vị thực hiện } & \multicolumn{1}{|c|}{ Tên gói thầu } \\
\hline 1 & CTCP Tư vấn xây dựng Bắc Thái & Tư vấn lập dự án \\
\hline 2 & Tiểu đoàn 93 & Rà phá bom mìn \\
\hline 3 & CTCP tư vấn và xây dựng Hưng Bình & Thẩm tra tổng mức báo cáo nghiên cứu khả thi \\
\hline 4 & CTCP tư vấn xây dựng BTH Thái Nguyên & $\begin{array}{l}\text { Tư vấn lập hồ sơ mời thầu, đánh giá hồ sơ dự } \\
\text { thâu }\end{array}$ \\
\hline 5 & $\begin{array}{l}\text { Cảnh sát phòng cháy chữa cháy tỉnh Thái } \\
\text { Nguyên }\end{array}$ & $\begin{array}{l}\text { Phí thẩm duyệt thiết kế về phòng cháy chữa } \\
\text { cháy }\end{array}$ \\
\hline 6 & CTCP kiến trúc xây dựng VN ASEAN & Thẩm tra hồ sơ thiết kế bản vẽ thi công \\
\hline 7 & CTCP Tư vấn xây dựng Bắc Thái & Tư vấn lập bản vẽ thiết kế thi công \\
\hline 8 & Công ty TNHH xây dựng Đông Bắc & $\begin{array}{l}\text { Thi công hạng mục giao thông, san nền, thoát } \\
\text { nước }\end{array}$ \\
\hline 9 & CTCP xây lắp và Thương mại Nhật Huy & Thi công hạng mục cấp điện \\
\hline
\end{tabular}

Nguồn: Quỹ Đầu tư phát triển tỉnh Thái Nguyên và tổng hợp của tác giả

\section{Quản lý lựa chọn nhà thầu}

Kết quả điều tra cho thấy $83.7 \%$ ý kiến đồng ý với cách thức quản lý lựa chọn nhà thầu. Các ý kiến đồng thuận đề cập đến vấn đề các nhà thầu có đủ năng lực pháp lý thực hiện gói thầu và thời gian lựa chọn nhà thầu phù hợp với quy định pháp luật. Đa phần các nhà thầu khi tham gia đấu thầu để thực hiện gói thầu đều có năng lực phù hợp với quy mô dự án đầu tư xây dựng trên phương diện pháp lý. Các nhà thầu đã đưa ra những phương án về việc bố trí nhân sự, vật liệu, vật tư và thiết bị thi công các gói thầu một cách khá hợp lý, bên cạnh đó nhà thầu thực hiện các gói thầu xây dựng theo đúng hợp đồng mặc dù có nhiều yếu tố tác động đến tiến độ nhưng về mặt tổng thể thì đã đáp ứng khá tốt yêu cầu tiến độ so với kế hoạch đề ra. Tuy nhiên vẫn còn $16.3 \%$ số ý kiến cho rằng cần phải xem lại cách quản lý lựa chọn nhà thầu. Do một số nhà thầu có đầy đủ năng lực pháp lý nhưng khi thực hiện các gói thầu về tư vấn hoặc thi công vẫn thể hiện năng lực yếu, chưa đáp ứng được tiến độ và chất lượng đã thỏa thuận trong hợp đồng. Chẳng hạn dự án Khu dân cư và khu tái định cư xóm Trung, xã Điềm Thụy, huyện Phú Bình trong phần lập dự án, đơn vị tư vấn mất nhiều thời gian để lập, chỉnh sửa lại các hạng mục trong gói thầu dẫn đến tình trạng chậm tiến độ so với hợp đồng đã ký kết.

\section{Quản lý chất lượng xây dụng}

Kết quả điều tra về quản lý chất lượng xây dựng cho thấy $88.8 \%$ ý kiến nhận định quản lý chất lượng xây dựng ở mức bình thường. Đa phần các ý kiến đều cho rằng chất lượng đầu tư xây dựng ngoài thực địa cần được nâng cao hơn, đặc biệt là máy móc, chất lượng đào đắp, độ chặt nền đất và chất lượng vật liệu xây dựng. Đa phần các bên có liên quan đều đồng thuận về vấn đề quản lý tại thực địa là đảm bảo đúng kế hoạch. Hàng tuần Chủ đầu tư là Quỹ đều có cuộc họp giao ban với đơn vị thi công xây dựng, đơn vị giám sát được chủ đầu tư thuê và Ban quản lý dự án của tỉnh. Các biện pháp kỹ thuật được nhà thầu thi công đưa ra có mức phù hợp tương đối với các gói thầu. Mức độ chính xác của khối lượng công việc theo thiết kế và phương pháp kỹ thuật thi công cũng đã đảm bảo được chất lượng xây dựng. Tiến độ dự án mặc dù chưa đảm bảo nhưng đã có sự cố 
gắng đẩy nhanh tiến độ dự án. Bên cạnh đó, việc thi công đã đảm bảo an toàn lao động và vệ sinh môi trường khu vực xung quanh dự án. Mức độ huy động và sử dụng các nguồn lực phù hợp với từng công việc để đảm bảo tiến độ thực hiện dự án.

Tuy nhiên vẫn tồn tại 11.2\% ý kiến không đồng ý với vấn đề quản lý chất lượng xây dựng, nguyên nhân chủ yếu là do chất lượng thi công ngoài thực địa chưa được đảm bảo như trong hợp đồng xây lắp. Chẳng hạn, dự án Khu dân cư số 4 , phường Tân Thịnh tại thời điểm thi công và chưa có biên bản bàn giao cụ thể giữa đơn vị thi công và Chủ đầu tư nhưng đã xuất hiện những chỗ xuống cấp, nắp cống bị nứt, vỡ hoặc vỉa hè bị bong gạch. Hoặc nền đường phần bên trong dự án của Khu dân cư số 10 phường Phan Đình Phùng có dấu hiệu xuống cấp do ô tô chở vật liệu chạy nhiều trong khu dân cư này dẫn đến mặt đường khi nghiệm thu không ổn định. Các phần không ổn định như trên đều được Chủ đầu tư liên hệ với nhà thầu thi công có biện pháp xử lý như vá hoặc làm lại phần đường đã xuống cấp, thay mới sửa chữa lại phần nắp cống vỉa hè đã hư hỏng...

\section{Quản lý tiến độ thi công dụ án}

Kết quả điều tra cho thấy $57.8 \%$ ý kiến bình thường về nhà thầu thi công thực hiện đúng tiến độ dự án và tiến độ thực hiện theo kế hoạch đã phê duyệt. Nguyên nhân chủ yếu là do yếu tố con người và thời tiết ảnh hưởng đến tiến độ dự án. Chẳng hạn, dự án Khu dân cư số 10 phường Phan Đình Phùng hoặc Khu dân cư số $3 \& 4$ phường Trưng Vương về công tác đền bù, giải phóng mặt bằng đều phức tạp và tiến hành chậm. Nguyên nhân dẫn tới những việc đó là do người dân chưa đồng thuận với mức giá đền bù đã đưa ra mặc dù đã có hỗ trợ tái định cư tại chỗ, như vậy việc chậm tiến độ thực hiện dự án sẽ xảy ra ảnh hưởng tới các giai đoạn thi công phía sau. Các dự án còn lại như Khu dân cư số 4 thị trấn Hương Sơn, huyện Phú Bình và Khu dân cư số 6 phường Thịnh Đán cũng chậm tiến độ thi công san lấp do yếu tố ngoại cảnh là thời tiết gây nên. Thời tiết đổ mưa gây ngập nước khiến cho máy xúc, máy ủi hay xe chở đất không thể thực hiện được công việc dẫn tới tiến độ thi công bị chậm lại. Kết quả điều tra cũng cho thấy $42.2 \%$ ý kiến đồng ý cho rằng cán bộ thực hiện đúng việc giám sát tiến độ dự án. Điều đó là Quỹ là Chủ dự án luôn có họp giao ban hàng tuần và đôn đốc các bên có liên quan thực hiện tiến độ dự án theo đúng kế hoạch đã đề ra. Trong đó Quỹ giao cho cán bộ chuyên môn thuộc các phòng thực hiện dự án phải giám sát đúng theo kế hoạch, phòng chuyên môn phải có kế hoạch theo ngày, tuần, tháng để phân công cán bộ xuống thực địa nơi thực hiện dự án tiến hành giám sát cùng đơn vị thuê giám sát độc lập.

\section{Bảng 4}

Chênh lệch thời gian thi công các gói thầu của dự án Khu dân cư số 4 phường Tân Thịnh, thành phố Thái Nguyên

\begin{tabular}{|c|l|l|c|c|c|c|}
\hline TT & Gói thầu & $\begin{array}{c}\text { Tên nhà thầu } \\
\text { thực hiện }\end{array}$ & $\begin{array}{c}\text { Thời gian theo } \\
\text { hợp đồng }\end{array}$ & $\begin{array}{c}\text { Thời gian } \\
\text { thực hiện }\end{array}$ & $\begin{array}{l}\text { Thời gian } \\
\text { phát sinh }\end{array}$ & Nguyên nhân \\
\hline 1 & $\begin{array}{l}\text { Xây lắp di chuyển } \\
\text { đường dây 22KV và } \\
\text { 35KV }\end{array}$ & $\begin{array}{l}\text { Công ty TNHH } \\
\text { dầu tư xây dưng } \\
\text { Ánh Dương }\end{array}$ & 2.0 & 3.0 & 1.0 & $\begin{array}{l}\text { Do vướng mặt } \\
\text { bằng dẫn tới } \\
\text { tiến độ chậm }\end{array}$ \\
\hline 2 & $\begin{array}{l}\text { Thi công suối, cầu } \\
\text { cống (gói số 1) }\end{array}$ & CTCP Minh Trâm & 4.0 & 4.0 & 0.0 & $\begin{array}{l}\text { Hoàn thành } \\
\text { đúng tiến độ }\end{array}$ \\
\hline 3 & $\begin{array}{l}\text { Gói thầu thi công } \\
\text { suối, cầu cống (gói } \\
\text { số } 2 \text { ) }\end{array}$ & $\begin{array}{l}\text { Công ty TNHH } \\
\text { XD DV Xuân } \\
\text { Tiến Hòa Bình }\end{array}$ & 4.0 & 5.0 & 1.0 & $\begin{array}{l}\text { Vướng mặt } \\
\text { bằng dẫn tới } \\
\text { tiến độ chậm }\end{array}$ \\
\hline 4 & $\begin{array}{l}\text { Thi công san nền, } \\
\text { đường giao thông, }\end{array}$ & CTCP Minh Trâm & 6.0 & 6.0 & 0.0 & $\begin{array}{l}\text { Hoàn thành } \\
\text { đúng tiến độ }\end{array}$ \\
\hline
\end{tabular}




\begin{tabular}{|c|c|c|c|c|c|c|}
\hline TT & Gói thầu & $\begin{array}{l}\text { Tên nhà thầu } \\
\text { thực hiện }\end{array}$ & $\begin{array}{c}\text { Thời gian theo } \\
\text { hợp đồng }\end{array}$ & $\begin{array}{l}\text { Thời gian } \\
\text { thực hiện }\end{array}$ & $\begin{array}{l}\text { Thời gian } \\
\text { phát sinh }\end{array}$ & Nguyên nhân \\
\hline & thoát nước (gói số 1) & & & & & \\
\hline 5 & $\begin{array}{l}\text { Thi công san nền, } \\
\text { đường giao thông, } \\
\text { thoát nước (gói số } 2 \text { ) }\end{array}$ & $\begin{array}{l}\text { Công ty TNHH } \\
\text { XD \& DV Xuân } \\
\text { Tiến Hòa Bình }\end{array}$ & 6.0 & 7.0 & 1.0 & $\begin{array}{l}\text { Do phát sinh } \\
\text { khối lượng } \\
\text { trong quá trình } \\
\text { thi công }\end{array}$ \\
\hline 6 & $\begin{array}{l}\text { Xây dựng và lắp đặt } \\
\text { hệ thống cấp điện }\end{array}$ & $\begin{array}{l}\text { CTCP xây lắp \& } \\
\text { thương mại Nhật } \\
\text { Huy }\end{array}$ & 2.0 & 2.5 & 0,5 & $\begin{array}{l}\text { Do điều kiện } \\
\text { thời tiết xấu }\end{array}$ \\
\hline 7 & $\begin{array}{l}\text { Tháo dỡ, lắp đặt, } \\
\text { vận chuyển di dời } \\
\text { cột điện đường } \\
\text { Quang Trung }\end{array}$ & $\begin{array}{l}\text { CTCP môi trường } \\
\text { \& công trình đô } \\
\text { thị Thái Nguyên }\end{array}$ & 1.0 & 1.5 & 0,5 & $\begin{array}{l}\text { Do điều kiện } \\
\text { thời tiết xấu }\end{array}$ \\
\hline
\end{tabular}

Nguồn: Quỹ Đầu tư phát triển tỉnh Thái Nguyên và tính toán của tác giả

Trên thực tế có nhiều nguyên nhân ảnh hưởng tới tiến độ thi công các gói thầu trong cùng một dự án. Theo bảng 4 , nguyên nhân ảnh hưởng đến tiến độ thi công gói xây lắp di chuyển đường dây $22 \mathrm{kv}$ và $35 \mathrm{kv}$ là do vướng mặt bằng. Trong quá trình di chuyển đường dây cần phối hợp của người dân trong khu vực dự án, nguyên nhân là do khi di chuyển đường sẽ có những ảnh hưởng nhất định đến quá trình sinh hoạt và sản xuất của người dân. Quá trình thi công gói thầu di chuyển đường điện không liên tục dẫn tới việc chậm tiến độ thi công của nhà thầu. Đối với gói thầu thi công san nền, đường giao thông cũng có nguyên nhân do vướng mặt bằng. Hợp đồng được ký giữa Chủ đầu tư là Quỹ và nhà thầu thi công trong 06 tháng và thực hiện từ ngày cố định có nêu trong hợp đồng thi công xây lắp, tuy nhiên quá trình trước đó do việc bồi thường giải phóng mặt bằng không được thuận lợi, mặt bằng thi công không được bàn giao đúng thời gian dẫn đến gói thầu thi công san nền, đường giao thông khởi công chậm trề so với thời gian dự tính. Các gói thầu nhỏ hơn như lắp đặt hệ thống cấp điện hay di chuyển cột điện thì còn phụ thuộc nhiều vào thời tiết trong khoảng thời gian đó. Gói thầu này được thực hiện nếu như thời tiết không có mưa, nhưng thời tiết xấu và mưa kéo dài cũng dẫn tới chậm tiến độ thi công.

\section{Quản lý chi phí thực hiện dụ án}

Kết quả điều tra các bên có liên quan về quản lý chi phí thực hiện dự án cho thấy $73.4 \%$ ý kiến đồng ý cho rằng chi phí giải ngân đúng tiến độ và các khâu trong việc giải ngân chi phí thực hiện tốt. Theo hợp đồng giữa Chủ đầu tư là Quỹ và các đơn vị thi công thì việc giải ngân cho gói thầu được thực hiện theo tiến độ thực hiện các gói thầu đó. Khi đơn vị thi công hoàn thiện một bước trong gói thầu thi công sẽ báo cáo chủ đầu tư và đơn vị tư vấn giám sát tiến hành nghiệm thu tại thực địa và có biên bản nghiệm thu. Sau một bước thi công đó được nghiệm thu thì đơn vị thi công có quyền yêu cầu chủ đầu tư giải ngân theo tiến độ thi công. Chủ đầu tư đã thực hiện tốt tiến độ giải ngân theo hợp đồng, các khâu giải ngân đang dần hoàn thiện để giảm thiểu các thủ tục trong việc giải ngân cho các gói thầu thi công.

Các ý kiến nhận định ở mức độ bình thường chiếm $26.6 \%$ chủ yếu là về phần nhà thầu thực hiện đúng theo kế hoạch chi. Trong mỗi dự án luôn phát sinh những công việc khác nhau nên nhà thầu thực hiện kế hoạch chi đôi khi chưa đúng. Chẳng hạn, trong việc thi công đào đất để bóc khối lượng đất mặt có kế hoạch trong vòng một tháng, tuy nhiên có thể do ảnh hưởng thời tiết hoặc máy xúc, đào bị hỏng ảnh hưởng tới tiến độ thực hiện công việc dẫn tới kế hoạch của nhà thầu bị chậm, không thực hiện đúng với kế hoạch chi. Như vậy, kế hoạch chi đối với các hạng mục tiếp theo bị 
chậm lại, gây ảnh hưởng tới tiến độ dự án.

\subsubsection{Công cu quản lý dụ án đầu tư tại Quỹ Đầu tư phát triển tỉnh Thái Nguyên}

\section{Công cu pháp luật}

Quản lý dự án đầu tư xây dựng tại Quỹ Đầu tư phát triển tỉnh Thái Nguyên được thực hiện thông qua các công cụ pháp luật bao gồm: các văn bản pháp lý của các cơ quan có thẩm quyền cấp phép thực hiện dự án và hợp đồng giữa Quỹ và các đơn vị tư vấn, thi công trong quá trình thực hiện dự án và tổ chức bộ máy của Quỹ để quản lý dự án đầu tư xây dựng. Bảng 5 minh họa một số văn bản pháp lý dự án Khu dân cư số 10 , cụ thể:

\section{Bảng 5}

Một số văn bản pháp lý dự án Khu dân cư số 10 phường Phan Đình Phùng

\begin{tabular}{|c|c|c|c|}
\hline STT & $\begin{array}{c}\text { Số văn } \\
\text { bản }\end{array}$ & $\begin{array}{l}\text { Cơ quan } \\
\text { phát hành }\end{array}$ & Nội dung văn bản \\
\hline 01 & 2228/QĐ & UBND tỉnh & $\begin{array}{l}\text { V/v phê duyệt dự án đầu tư xây dựng công trình xây dựng cơ sở hạ tầng } \\
\text { khu dân cư số } 10\end{array}$ \\
\hline 02 & 966/QĐ & UBND tỉnh & V/v phê duyệt quy hoạch chi tiết tỷ lệ $1 / 500$ khu dân cư số 10 \\
\hline 03 & 1855/QĐ & UBND tỉnh & V/v điều chỉnh quy hoạch chi tiết tỷ lệ $1 / 500$ \\
\hline 04 & 2456/QĐ & UBND tỉnh & V/v phê duyệt điều chỉnh cục bộ quy hoạch chi tiết \\
\hline 05 & 2228/QĐ & UBND tỉnh & V/v phê duyệt dự án đầu tư xây dựng công trình \\
\hline 06 & 3058/QĐ & UBND tỉnh & V/v phê duyệt điều chỉnh tổn mức đầu tư dự án \\
\hline 07 & 276/QĐ & UBND tỉnh & $\begin{array}{l}\text { V/v phê duyệt chi phí khảo sát địa hình là lập điều chỉnh quy hoạch chi } \\
\text { tiết }\end{array}$ \\
\hline 08 & 53B/QĐ & Quỹ Đầu tư & V/v chỉ định thầu bảo hiểm công trình xây dựng cơ sở hạ tầng khu dân cư \\
\hline 09 & $526 / \mathrm{CV}$ & $\begin{array}{l}\text { Sở } \\
\mathrm{TN} \& \mathrm{MT}\end{array}$ & $\begin{array}{l}\text { V/v thẩm định dự toán trích đo thành lập bản đồ địa chính phục vụ xây } \\
\text { dựng cơ sở hạ tầng khu dân cư }\end{array}$ \\
\hline 10 & 27B/QĐ & Quỹ Đầu tư & $\begin{array}{l}\text { V/v chỉ định thầu trích đo bản đồ địa chính phục vụ công tác giao đất cấp } \\
\text { quyền sử dụng đất }\end{array}$ \\
\hline 11 & 05A2/QĐ & Quỹ Đầu tư & $\begin{array}{l}\text { V/v phê duyệt chỉ định thầu gói thầu tư vấn giám sát thi công công trình } \\
\text { xây dựng cơ sở hạ tầng khu dân cư số } 10\end{array}$ \\
\hline 12 & 37B/QĐ & Quỹ Đầu tư & V/v điều chỉnh gói thầu xây lắp giao thông, san nền, thoát nước \\
\hline 13 & 63/QĐ & Quỹ Đầu tư & V/v phê duyệt hồ sơ thiết kế bản vẽ thi công dự toán điều chỉnh bổ sung \\
\hline 14 & $62 / \mathrm{Q}$ & Quỹ Đầu tư & $\begin{array}{l}\text { V/v bổ sung giá trị gói thầu xây lắp: san nền, đường giao thông, hệ thống } \\
\text { thoát nước, công trình xây dựng cơ sở hạ tầng khu dân cư số } 10\end{array}$ \\
\hline 15 & $53 \mathrm{~A} / \mathrm{Q} \bigoplus$ & Quỹ Đầu tư & $\begin{array}{l}\text { V/v phê duyệt dự toán điều chỉnh bổ sung công trình xây dựng cơ sở hạ } \\
\text { tầng khu dân cư số } 10\end{array}$ \\
\hline 16 & 36B/QĐ & Quỹ Đầu tư & $\begin{array}{l}\text { V/v phê duyệt điều chỉnh gói thầu xây lắp: san nền, đường giao thông, hệ } \\
\text { thống thoát nước, công trình xây dựng cơ sở hạ tầng khu dân cư số } 10\end{array}$ \\
\hline
\end{tabular}

Nguồn: Quỹ Đầu tư phát triển tỉnh Thái Nguyên và tổng hợp của tác giả

\section{Công cu kế hoạch}

Trên thực tế mỗi dự án bao gồm rất nhiều gói thầu tư vấn và thi công. Mỗi gói thầu tư vấn hoặc thi công đều kèm theo là hợp đồng giữa chủ đầu tư và đơn vị tư vấn hoặc thi công. Trong 
hợp đồng cũng có các mục về thời gian và tiến độ thực hiện hợp đồng xây dựng. Các đơn vị thực hiện các gói thầu đều phải có kế hoạch thực hiện như kế hoạch thực hiện gói thầu tư vấn lập quy hoạch 1/500, kế hoạch thực hiện lập báo cáo nghiên cứu khả thi, kế hoạch thực hiện thi công... Căn cứ vào kế hoạch thực hiện các gói thầu trên, Chủ đầu tư là Quỹ sẽ tiến hành giám sát kế hoạch đã trình của đơn vị tư vấn, qua đó quản lý được kế hoạch đó giúp cho dự án hoàn thành đúng theo kế hoạch đã đề ra. Bảng 6 minh họa kế hoạch thực hiện gói thầu tư vấn lập báo cáo đánh giá tác động môi trường của một dự án thuộc Quỹ bao gồm thời gian 40 ngày làm việc. Quỹ căn cứ vào kế hoạch do đơn vị tư vấn trình theo dõi các bước trong quá trình lập báo cáo và trình phê duyệt báo cáo. Nếu như tiến độ chậm hơn so với kế hoạch, Quỹ sẽ có ý kiến với đơn vị tư vấn để đẩy nhanh tiến độ thực hiện gói thầu tránh làm ảnh hưởng tới tiến độ chung của dự án.

\section{Bảng 6}

Kế hoạch thực hiện lập, phê duyệt báo cáo đánh giá tác động môi trường

\begin{tabular}{|c|l|c|c|}
\hline STT & \multicolumn{1}{|c|}{ Nội dung công việc } & $\begin{array}{c}\text { Dự kiến thời gian } \\
\text { thực hiện (ngày) }\end{array}$ & Ghi chú \\
\hline 01 & Khảo sát thực địa & 1.0 & \\
\hline 02 & Lấy ý kiến cộng đồng dân cư & 2.0 & \\
\hline 03 & Họp các cơ quan chức năng liên quan tới dự án & 1.0 & \\
\hline 04 & Lấy mẫu đất, nước, không khí & 1.0 & \\
\hline 05 & Viết báo cáo đánh giá tác động môi trường dự án & 10.0 & \\
\hline 06 & Trình thẩm định báo cáo lần thứ nhất & 5.0 & \\
\hline 07 & Chỉnh sửa báo cáo sau thẩm định & 5.0 & \\
\hline 08 & Trình thẩm định báo cáo lần thứ hai & 5.0 & \\
\hline 09 & Trình phê duyệt báo cáo đánh giác tác động môi trường & 10.0 & \\
\hline
\end{tabular}

Nguồn: Quỹ Đầu tư phát triển tỉnh Thái Nguyên và tổng hợp của tác giả

\section{Công cu mục lục ngân sách}

Theo Điều lệ tổ chức và hoạt động của Quỹ Đầu tư phát triển tỉnh Thái Nguyên đã được UBND tỉnh Thái Nguyên phê duyệt, hàng năm căn cứ vào khả năng ngân sách tỉnh, UBND tỉnh cân đối trong dự toán ngân sách, trình Hội đồng nhân tỉnh để bổ sung vốn theo quy định, chẳng hạn quyết định về việc giao kế hoạch phát triển kinh tế - xã hội năm 2016, 2017 và 2018 (Bảng 7). Quỹ căn cứ vào công cụ mục lục ngân sách nêu trên và nguồn vốn chủ sở hữu hiện đang có thực hiện các dự án hướng tới mục tiêu phát triển kinh tế xã hội địa phương. Bên cạnh đó Quỹ cũng căn cứ vào ngân sách hàng năm phân bổ để thực hiện các dự án.

\section{Bảng 7}

Quyết định về việc giao kế hoạch phát triển kinh tế - xã hội

\begin{tabular}{|c|c|c|l|}
\hline STT & Số quyết định & $\begin{array}{c}\text { Co quan phê } \\
\text { duyệt }\end{array}$ & \multicolumn{1}{c|}{ Nội dung } \\
\hline 1 & $3525 / \mathrm{D}$ & UBND tỉnh & $\begin{array}{l}\text { V/v giao kế hoạch phát triển kinh tế - xã hội } \\
\text { năm 2016 tỉnh Thái Nguyên }\end{array}$ \\
\hline 2 & $3878 / \mathrm{Q} Đ$ & UBND tỉnh & V/v giao kế hoạch phát triển kinh tế - xã hội \\
\hline
\end{tabular}




\begin{tabular}{|c|c|c|l|}
\hline STT & Số quyết định & $\begin{array}{c}\text { Co quan phê } \\
\text { duyệt }\end{array}$ & \multicolumn{1}{c|}{ Nội dung } \\
\hline & & & năm 2017 tỉnh Thái Nguyên \\
\hline 3 & $3838 / Q Đ$ & UBND tỉnh & $\begin{array}{l}\text { V/v giao kế hoạch phát triển kinh tế - xã hội } \\
\text { năm 2018 tỉnh Thái Nguyên }\end{array}$ \\
\hline
\end{tabular}

Nguồn: Quỹ Đầu tư phát triển tỉnh Thái Nguyên và tổng hợp của tác giả

\section{Công cu hạch toán kế toán}

Để thực hiện quản lý dự án đầu tư xây dựng, cán bộ chuyên môn thuộc Quỹ sử dụng phần mềm lập dự toán G8 để phân tích, định lượng và đánh giá trước kết quả của các gói thầu trong dự án. Từ đó tham mưu cho Ban Giám đốc Quỹ các phương án thực hiện gói thầu tư vấn hoặc thi công đạt hiệu quả cao nhất. Phòng tài chính kế toán thuộc Quỹ sử dụng phần mềm kế toán Misa để theo dõi chi phí, công nợ và cập nhật chứng từ sổ sách theo quy định. Trong các gói thầu tư vấn hoặc thi công luôn phải đi kèm với các chứng từ và thuế, Phòng tài chính kế toán dựa vào phần mềm nói trên thực hiện chi trả và theo dõi các khoản theo đúng quy định. Ngoài ra, Phòng tài chính kế toán còn sử dụng phần mềm HTKK để hỗ trợ kê khai thuế thực hiện các công tác chuyên môn và công tác thanh quyết toán của Quỹ (Bảng 8).

\section{Bảng 8}

Tình hình sử dụng công cụ hạch toán kế toán

\begin{tabular}{|c|c|l|}
\hline STT & Tên công cụ & \multicolumn{1}{c|}{ Nội dung } \\
\hline 01 & Phần mềm lập dự toán G8 & $\begin{array}{l}\text { Phân tích, định lượng, đánh giá kết quả của các công } \\
\text { trình trong dự án }\end{array}$ \\
\hline 02 & Phần mềm HTKK & Hỗ trợ kê khai thuế \\
\hline 03 & Phần mềm kế toán Misa & $\begin{array}{l}\text { Theo dõi chi phí, công nợ, cập nhật chứng từ sổ sách } \\
\text { theo quy định. Kềt nối vời phần mềm ngánh thuế, có } \\
\text { đây đủ các chế độ chính sách mà kế toán yêu cầu }\end{array}$ \\
\hline
\end{tabular}

Nguồn: Quỹ Đầu tư phát triển tỉnh Thái Nguyên và tổng hợp của tác giả

\section{2. Đánh giá quản lý dụ án đầu tư tại Quỹ Đầu tư phát triển tỉnh Thái Nguyên}

\subsubsection{Kết quả đạt được}

- Quy trình quản lý dụ án đầu tux xây dưng: đã hoàn thiện bước đầu, quy trình công việc rõ ràng, có sự phân công tới các phòng chuyên môn và cán bộ chuyên môn thực hiện dự án. Trong quá trình thực hiện dự án, Quỹ đã tạo được quy trình từ bước nghiên cứu, lập quy hoạch đến lập dự án và thi công xây lắp.

- Nội dung quản lý dư án đầu tux xây dụng: đã bao gồm đầy đủ các nội dung cần phải có để quản lý một dự án đầu tư xây dựng cụ thể như lập, thẩm định, lựa chọn nhà thầu tư vấn hoặc thi công, quản lý về chất lượng, tiến độ và quản lý về chi phí thực hiện dự án.

- Công cu quản lý dụ án đầu tu xây dụng: đã đầy đủ tính pháp lý và thực tiễn. Hợp đồng có ý nghĩa rất quan trọng trong việc thực hiện các gói thầu của dự án hoặc công cụ kế hoạch thì chủ đầu tư đã giám sát chặt chẽ thông qua các cuộc giao ban hàng tuần nhằm vận hành tiến độ dự án theo đúng kế hoạch đã đề ra. 


\subsubsection{Hạn ché}

- Quy trình quản lý dụ án đầu tux xây dựng: Quy trình thực hiện đối với mỗi dự án có sự phân cấp về tổng mức và quy mô khác nhau là khác biệt. Do vậy hạn chế của quy trình quản lý dự án tại Quỹ là chưa bao gồm hết được các dự án có tổng mức đầu tư lớn thuộc các nhóm $\mathrm{A}, \mathrm{B}$ theo quy định của nhà nước. Chủ yếu Quỹ thực hiện dự án đa số vẫn thuộc nhóm $\mathrm{C}$.

- Nội dung quản lý dụ án đầu tu xây dưng: Mặc dù đã bao gồm đầy đủ các nội dung quản lý dự án đầu tư xây dựng, tuy nhiên việc thực hiện các nội dung cụ thể cần phải chặt chẽ hơn nữa, chẳng hạn quản lý chất lượng xây dựng hoặc quản lý tiến độ thi công dự án. Chất lượng tại một số hạng mục như nắp cống hộp mương nước và vỉa hè bị xuống cấp, vỡ, hỏng sau khi thi công được một thời gian. Tiến độ thi công dự án chưa đúng theo kế hoạch đã đề ra.

- Công cu quản lý dụ án đầu tu xây dưng: Trong hợp đồng chưa có những điều khoản về xử phạt khi vi phạm thời hạn, thời gian. Cụ thể khi đơn vị tư vấn hoặc thi công làm chậm so với tiến độ theo kế hoạch thì chưa có mức xử lý vi phạm tương ứng. Phần mục lục ngân sách hàng năm còn hạn chế về khoản ngân sách bổ sung vốn điều lệ cho Quỹ.

\subsubsection{Nguyên nhân của nhũng hạn chế}

- Quy trình trình quản lý dụ án đầu tux xây dụng: Vốn điều lệ thấp nên chưa thực hiện được những dự án lớn do đó chưa bổ sung, hoàn thiện quy trình quản lý dự án. Bên cạnh đó là sự đa dạng của các dự án dẫn đến việc hoàn thiện quy trình quản lý dự án gặp khó khăn.

- Nội dung quản lý dụ án đầu tu xây dụng: Yếu tố thời tiết xấu ảnh hưởng tới tiến độ thi công dự án, yếu tố con người như người dân không nhận đền bù cũng ảnh hưởng tới tiến độ giải phóng mặt bằng gây ra chậm trễ đến kế hoạch chung của dự án. Năng lực hạn chế của chủ đầu tư và các đơn vị tư vấn, thi công đã gây ảnh hưởng đến nội dung quản lý dự án.

- Công cu quản lý dư án đầu tur xây dựng: Các văn bản Luật, Nghị định và các văn bản khác có liên quan chưa có quy định pháp lý thông thoáng đối với hoạt động của quỹ đầu tư phát triển địa phương nói chung và Quỹ Đầu tư phát triển tỉnh Thái Nguyên nói riêng, đặc biệt là công tác quản lý dự án, nguồn vốn thực hiện, nguồn cấp bổ sung vốn điều lệ để thực hiện dự án.

\section{Thái Nguyên}

\subsection{Giải pháp hoàn thiện quản lý dụ án đầu tư tại Quỹ đầu tư phát triển tỉnh}

\subsubsection{Hoàn thiện quy trình quản lý dụ án đầu tux xây dưng}

- Tổ chức hội nghị chuyên đề về quy trình quản lý dự án, từ đó bổ sung các phần khuyết thiếu, hoàn thiện quy trình mang tính chất chung, có tính khả thi được triển khai thực hiện đối với toàn bộ các Quỹ đầu tư phát triển địa phương trên cả nước.

- Tổ chức các chuyến trải nghiệm thực tế để học hỏi kinh nghiệm tại các Quỹ đầu tư phát triển địa phương thành lập trước, tham khảo cách thức thực hiện dự án. Qua đó đúc rút kinh nghiệm quản lý quy trình thực hiện dự án, tiến hành thực hiện dự án.

- Báo cáo cơ quan Nhà nước có thẩm quyền về quản lý dự án đầu tư xây dựng để xây dựng một quy trình bao quát tổng thể đối với quản lý dự án đầu tư xây dựng áp dụng chung cho khối ngành có liên quan.

\subsubsection{Hoàn thiện nội dung quản lý dụ án đầu tư xây dụ̂ng}

- Quản lý quá trình lập dự án (báo cáo nghiên cứu khả thi): Trong giai đoạn lập dự án, Quỹ cần phân công phòng chuyên môn nghiệp vụ giám sát chặt chẽ đơn vị tư vấn lập dự án, từ công việc đo đạc, lấy mẫu, kiểm đếm ngoài thực địa... sao cho đảm bảo chất lượng của công tác 
lập dự án. Ngoài ra cần yêu cầu đơn vị tư vấn đảm bảo được thời gian thực hiện gói thầu lập dự án đúng như cam kết trong hợp đồng đã được ký kết.

- Quản lý quá trình thẩm định: Quá trình thẩm định chủ yếu là về chất lượng, kỹ thuật và công nghệ đúng yêu cầu thực tế của các gói thầu. Cán bộ thẩm định cần được trang bị đầy đủ những kiến thức về thẩm định chất lượng, qua đó đánh giá được tính thực tế của các gói thầu tư vấn, tham mưu cho cấp trên ra quyết định đúng đắn và sáng suốt. Muốn trang bị kiến thức cập nhật và hiện đại cho cán bộ chuyên môn thì Quỹ cần tổ chức các lớp đào tạo chuyên sâu về thẩm định, cử cán bộ chuyên môn đi học các lớp đào tạo về lập dự án, kiểm soát dự án và thẩm định dự án, từ đó nâng cao năng lực chuyên môn cho cán bộ.

- Quản lý chi phí thực hiện dụ án: Cán bộ chuyên môn về kế toán của Quỹ cần xác định khối lượng và dự toán của khối lượng của dự án theo cách thận trọng và chính xác, đảm bảo dự án được phê duyệt dự toán và có hiệu quả. Quỹ cần yêu cầu trong quá trình thi công nhà thầu phải thực hiện theo bản vẽ thiết kế đã được phê duyệt, đảm bảo đúng chất lượng đã được phê duyệt, tuyệt đối không được thực hiện sai kỹ thuật, sai chất lượng, tránh lãng phí nguyên vật liệu. Quỹ cần cử cán bộ chuyên môn giám sát công tác thi công của nhà thầu, phối hợp với đơn vị tư vấn giám sát, tư vấn thiết kế nhằm kịp thời đưa ra các phương án tối ưu đảm bảo được chất lượng mà có thể giảm thiểu được chi phí thấp nhất. Đối với nguồn kinh phí thực hiện dự án phải có kế hoạch đối với từng hạng mục, từng giai đoạn cụ thể, tránh trường hợp chi trả chậm đối với các nhà thầu thi công làm chậm tiến độ của dự án.

- Quản lý lựa chọn nhà thầu: Đối với các nhà thầu tư vấn và thi công xây lắp, Quỹ cần dựa trên tiến độ thực hiện gói thầu và chất lượng thực hiện gói thầu để đánh giá chất lượng của nhà thầu đó. Từ đó Quỹ cần rút kinh nghiệm và xây dựng phương án trong quản lý lựa chọn nhà thầu được tốt hơn đối với các dự án tiếp theo.

- Quản lý chất lương xây dụng: Quỹ cần cử cán bộ chuyên môn giám sát các quá trình thực hiện thi công một cách sát sao, xây dựng lịch phân công cụ thể đối với từng cán bộ phụ trách giám sát, các cán bộ chuyên môn thường xuyên thay nhau theo lịch trình để giám sát được liền mạch. Thời gian thi công và thời gian giám sát phải tương đương nhau. Đơn vị được chủ đầu tư thuê giám sát cần phải thực hiện tốt chức năng giám sát đã cam kết trong hợp đồng.

- Quản lý tiến độ thi công: Dựa trên tiến độ thi công của nhà thầu thi công lập, cán bộ chuyên môn cần phải xem xét kỹ các yếu tố ảnh hưởng tới thi công như mặt bằng, thời tiết, nhân công, máy móc để có thể tham mưu cho Ban Giám đốc về tiến độ thi công của dự án đó. Cố định hàng tuần, tháng có họp giao ban giữa Chủ đầu tư, tư vấn giám sát và nhà thầu thi công. Nội dung cuộc họp là báo cáo tiến độ dự án của bên thi công, nhật ký thi công hàng ngày của nhà thầu thi công. Mọi việc phát sinh của thi công phải được báo cáo cho bên giám sát và chủ đầu tư trong cuộc họp, đồng thời cần phải đưa ra biện pháp xử lý đối với tình huống phát sinh đó.

Đối với từng hạng mục đã thi công xong, nhà thầu thi công phải báo cáo chủ đầu tư để tiến hành nghiệm thu trong từng giai đoạn. Nếu phát sinh hoặc chất lượng thi công không đảm bảo, phải có biện pháp chỉnh sửa hoặc thực hiện lại. Nhà thầu thi công phải có kế hoạch thực hiện cho từng hạng mục thi công. Kế hoạch đó phải đảm bảo khả thi, thực hiện được để tiếp tục triển khai các hạng mục tiếp theo. Chủ đầu tư - Quỹ phải kiên quyết xử lý những trường hợp làm sai thiết kế, không đúng tiến độ mà nhà thầu thi công đã đề ra nhằm thực hiện đúng tiến độ thi công đã cam kết trong hợp đồng. Đối với cán bộ chuyên môn phụ trách theo dõi thi công phải thường xuyên có mặt tại nơi thực hiện dự án, các trường hợp vi phạm hợp đồng thi công phải báo lại cấp trên để xin hướng giải quyết. Trường hợp thực hiện sai có thể yêu cầu dừng thi công, liên hệ với nhà thầu thi công yêu cầu thực hiện đúng. 


\subsubsection{Hoàn thiện công cu quản lý dư án đầu tu xây dụng}

- Công cu pháp luật: Quỹ cần thắt chặt về thời gian và tiến độ đã được xác định trong hợp đồng, bổ sung các điều khoản xử phạt nếu vi phạm hợp đồng về thời gian và tiến độ. Ngoài ra Quỹ cần có ý kiến bằng văn bản tham mưu với cấp trên về việc bổ sung nguồn vốn điều lệ để mở rộng hoạt động đầu tư của Quỹ.

- Công cu kế hoạch: Quỹ cần yêu cầu các nhà thầu tư vấn và thi công có kế hoạch thực hiện rõ ràng đối với các gói thầu, giám sát chặt chẽ việc thực hiện kế hoạch đó. Ngoài ra, Quỹ cần thường xuyên thông tin, trao đổi trực tiếp hoặc gián tiếp đối với các nhà thầu về tiến độ thực hiện kế hoạch mà nhà thầu đưa ra. Yêu cầu nhà thầu lập và ký bản cam kết thực hiện kế hoạch thi công theo đúng tiến độ đã đề ra.

- Công cu hạch toán kế toán: Quỹ cần đào tạo nâng cao trình độ chuyên môn đối với cán bộ có chuyên môn trong lĩnh vực tài chính, kế toán dự án. Chẳng hạn cử cán bộ tài chính, kế toán tham gia các lớp học ngắn hạn, dài hạn về tài chính, kế toán dự án và quản lý dự án.

- Công cu mục lục ngân sách: Quỹ cần có ý kiến tham mưu với UBND tỉnh đề xuất hàng năm có các nhiệm vụ thực hiện đầu tư trình Hội đồng nhân dân tỉnh phê duyệt làm căn cứ để Quỹ thực hiện đúng và đầy đủ chức năng, nhiệm vụ đã được cấp trên giao phó.

\subsection{Kiến nghị đối với các bên có liên quan}

\subsection{1. Đối với Chính phủ và các Bộ/Ngành có liên quan}

- Ban hành quy định cụ thể hóa địa vị pháp lý và mô hình tổ chức hoạt động của quỹ đầu tư phát triển địa phương nói chung và Quỹ Đầu tư phát triển tỉnh Thái Nguyên nói riêng, thông qua việc giải quyết những nội dung còn vướng mắc tại Nghị định số 37/2013/NĐ-CP ngày 22/04/2013 và Nghị định số 138/2007/NĐ-CP ngày 28/08/2007.

- Ban hành quy định cụ thể, thống nhất về mô hình hoạt động, bộ máy tổ chức của quỹ đầu tư phát triển địa phương nói chung và Quỹ Đầu tư phát triển tỉnh Thái Nguyên nói riêng.

- Điều chỉnh hoặc ban hành các văn bản hướng dẫn cụ thể các nội dung quy định tại Nghị định số 37/2013/NĐ-CP và Nghị định số 138/2007/NĐ-CP về các hoạt động của Quỹ đầu tư phát triển địa phương như: phát hành trái phiếu Quỹ, đầu tư trực tiếp...

\subsection{2. Đối với UBND tỉnh Thái Nguyên và các Sở/Ban/Ngành có liên quan}

- Thực hiện phân cấp, giao trách nhiệm cụ thể cho Quỹ trong việc phê duyệt một số nội dung liên quan đến hoạt động của Quỹ như: kế hoạch lao động, kế hoạch đầu tư, kế hoạch tài chính, quỹ lương kế hoạch và thực tế hàng năm của người lao động, viên chức quản lý tại Quỹ...

- Nghiên cứu bãi bỏ quy định các lĩnh vực đầu tư của Quỹ mà cho phép tùy theo điều kiện đặc thù của mình, xác định lĩnh vực ưu tiên phát triển kinh tế - xã hội để định hướng cho hoạt động đầu tư của Quỹ, đồng thời cho phép thực hiện các dự án đầu tư trực tiếp, góp vốn khác ngoài danh mục quy định nhưng theo đúng định hướng của HĐND, UBND cấp tỉnh.

- Hoàn thiện cơ chế chính sách, tăng cường công tác kiểm tra, giám sát đảm bảo Quỹ hoạt động đúng quy định, an toàn, hiệu quả và giảm rủi ro.

- Bổ sung nguồn vốn cho Quỹ theo quy định để phát huy hơn nữa hiệu quả hoạt động đầu tư trực tiếp; hỗ trợ về cơ chế, chính sách, tạo điều kiện thuận lợi để đầu tư.

- Chỉ đạo, phối hợp với Quỹ tháo gỡ những khó khăn, vướng mắc trong quá trình triển khai thực hiện chức năng, nhiệm vụ được giao phó. 
- Quan tâm, tạo điều kiện để Quỹ hoàn thiện cơ sở vật chất phục vụ hoạt động chuyên môn.

4.4.3. Đối với địa phương nơi có dụ án đầu tư xây dụng

- Tạo điều kiện, phối hợp cùng Quỹ thực hiện dự án tại địa phương.

- Chỉ đạo phòng ban có liên quan như Phòng Tài nguyên \& Môi trường, Phòng Kinh tế hạ tầng, Ban Bồi thường giải phóng mặt bằng huyện/thành phố phối hợp với Quỹ trong công tác quy hoạch, bồi thường, thi công trong dự án.

4.4.4. Đối với người dân nơi có dự án đầu tư xây dựng

- Trong công tác quy hoạch: Người dân cần có phản hồi với chủ đầu tư về các phương án quy hoạch, xem xét các phương án nào phù hợp với địa bàn nơi người dân đang sinh sống, từ đó chủ đầu tư là Quỹ có phương án thực hiện dự án một cách hợp lý, có hiệu quả.

- Trong công tác đền bù, giải phóng mặt bằng: Người dân cần phối hợp với Ban bồi thường giải phóng mặt bằng của huyện/thành phố và cán bộ chuyên môn thuộc Quỹ, nhằm đảm bảo tiến độ dự án, đảm bảo quyền lợi của mỗi người dân trong dự án.

\section{Kết luận}

Quỹ Đầu tư phát triển tỉnh Thái Nguyên là đơn vị mới thành lập từ năm 2016 với những thành tựu bước đầu trong lĩnh vực thực hiện dự án đầu tư xây dựng phục vụ phát triển hạ tầng, kinh tế - xã hội của tỉnh Thái Nguyên. Với mục tiêu thực hiện tốt chức năng và nhiệm vụ được UBND tỉnh Thái Nguyên giao phó nói chung và hoàn thiện quản lý dự án đầu tư xây dựng nói riêng, Quỹ Đầu tư phát triển tỉnh Thái Nguyên cần đánh giá hiện trạng quản lý dự án đầu tư xây dựng trong thời gian vừa qua, xây dựng phương hướng, xác định mục tiêu trong thời gian tới và thực hiện thành công một số giải pháp hoàn thiện quản lý dự án đầu tư xây dựng đã được đề cập, góp phần đáp ứng nhu cầu phát triển kinh tế - xã hội của địa phương.

\section{Tài liệu tham khảo}

Bộ Xây dựng. (2016). Thông tu số 06/TT-BXD ngày 10/3/2016 của Bộ Xây dưng Hướng dẫn xác định và quản lý chi phí đầu tu xây dụng [Circular 06/2012/TT-BXD dated 10 March 2016 by the Ministry of Construction guiding the determination and management of construction investment costs]. Retrieved October 20, 2019, from https://luatvietnam.vn/xaydung/thong-tu-06-2016-tt-bxd-bo-xay-dung-104155-d1.html\#taive

Bộ Xây dựng. (2017). Quyết định số 79/QĐ-BXD ngày 15/02/2017 của Bộ Xây dưng Công bố định mức chi phí quản lý dụ án và tư vấn đầu tu xây dụng [Decision 79/QD-BXD dated 15 February 2017 by the Ministry of Construction announcing the norm of project management costs and construction investment consultation]. Retrieved October 21, 2019, from https://luatvietnam.vn/xay-dung/quyet-dinh-79-qd-bxd-bo-xay-dung-112506d1.html\#taive

Chính phủ. (2007). Nghị định số 138/2007/NĐ-CP ngày 28/08/2007 về tổ chúc hoạt động của Quỹ đầu tu phát triển địa phuong [Decree 138/2007/ND-CP dated 28 August 2007 on the organization and operation of the local investment and development fund]. Retrieved October 23, 2019, from https://luatvietnam.vn/dau-tu/nghi-dinh-138-2007-nd-cp-chinhphu-32849-d1.html

Chính phủ. (2013). Nghị định số 37/2013/NĐ-CP ngày 22/04/2013 về sủa đổi, bổ sung một số điều của Nghị định số 138/2007/NĐ-CP ngày 28/08/2007 về tổ chức hoạt động của Quỹ đầu tu 
phát triển địa phuoong [Decree 37/2013/ND-CP dated 22 April 2013 Amending and supplementing a number of articles of Decree 138/2007/ND-CP dated 28 August 2007 on the organization and operation of the Fund investment in local development]. Retrieved October 24, 2019, from https://luatvietnam.vn/tai-chinh/nghi-dinh-37-2013-nd-cp-chinhphu-78103-d1.html

Chính phủ. (2015). Nghị định số 32/2015/NĐ-CP ngày 25/03/2015 của Chính phủ về quản lý chi phí đầu tu xây dưng công trình [Decree 32/2015/ND-CP dated 25 March 2015 of the Government on management of costs of construction investment]. Retrieved October 25 , 2019, from https://luatvietnam.vn/xay-dung/nghi-dinh-32-2015-nd-cp-chinh-phu-93348d1.html

Chính phủ. (2015). Quyết định số 260/QĐ-TTg ngày 27/02/2015 của Thủ tuoóng Chính phủ Phê duyệt Quy hoạch tổng thể phát triển kinh tế-xã hội tỉnh Thái Nguyên đến năm 2020 và tầm nhì đến năm 2030 [Decision 260/QD-TTg dated 27 February 2015 by the Prime Minister approves the master plan on socio-economic development of Thai Nguyen province to 2020 and vision to 2030]. Retrieved October 22, 2019, from https://luatvietnam.vn/chinhsach/quyet-dinh-260-qd-ttg-thu-tuong-chinh-phu-92906-d1.html

Dinh, H. V., Luong, T. T., \& Nguyen, D. P. (2013). Bài giảng gốc quản lý dụ án [Original project management lecture]. Hanoi, Vietnam: Nhà xuất bản Tài chính.

Mai, T. X. (2019). Luận văn thạc sĩ chuyên ngành quản lý kinh tế Quản lý dự án đầu tư xây dựng tại Quỹ Đầu tu phát triển tỉnh Thái Nguyên [Managing construction investment projects at Thai Nguyen Provincial Development Investment Fund] (Master's thesis, Thainguyen University of Economics and Business Administration, Vietnam). Retrieved October 27, 2019, from http://tailieudientu.lrc.tnu.edu.vn/chi-tiet/quan-ly-du-an-dau-tu-xay-dung-taiquy-dau-tu-phat-trien-tinh-thai-nguyen-146360.html

National Assembly of Vietnam. (2013). Land law. Retrieved May 11, 2019, from https://luatvietnam.vn/dat-dai/luat-dat-dai-2013-83386-d1.html

National Assembly of Vietnam. (2013). Law on bidding. Retrieved May 10, 2019, from https://luatvietnam.vn/dau-thau/luat-dau-thau-2013-83384-d1.html

National Assembly of Vietnam. (2014). Construction law. Retrieved May 14, 2019, from https://luatvietnam.vn/xay-dung/luat-xay-dung-2014-87928-d1.html

National Assembly of Vietnam. (2014). Law on investment. Retrieved May 13, 2019, from https://luatvietnam.vn/dau-tu/luat-dau-tu-2014-91358-d1.html

National Assembly of Vietnam. (2014). Law on public investment. Retrieved May 12, 2019, from https://luatvietnam.vn/dau-tu/luat-dau-tu-cong-2014-87927-d1.html

Ủy ban nhân dân tỉnh Thái Nguyên. (2017). Quyết định số 04/2017/QĐ-UBND ngày 15/02/2017 của Ủy ban nhân dân tỉnh Thái Nguyên Ban hành Quy định một số nội dung về quản lý dụ án đầu tu và xây dưng; quản lý về đấu thầu sủ dụng vốn nhà nước trên địa bàn tỉnh Thái Nguyên [Decision 04/2017/QD-UBND dated 15 February 2017 of the People's Committee of Thai Nguyen province, issuing Regulations on some contents on the management of investment and construction projects; management of bidding using state capital in Thai Nguyen province]. Retrieved October 28, 2019, from https://luatvietnam.vn/dau-tu/quyetdinh-04-2017-qd-ubnd-uy-ban-nhan-dan-tinh-thai-nguyen-113757-d2.html 